\title{
Is there any Relationship between Morning walk and Blood in Urine?
}

\author{
Muhammad Imran Qadir, Zeeshan Haider* and Mujahid Hussain \\ Institute of Molecular Biology and Biotechnology Bahauddin Zakariya University Multan, Pakistan
}

Submission: May 29, 2019; Published: June 20, 2019

*Corresponding author: Zeeshan Haider, Institute of Molecular Biology and Biotechnology Bahauddin Zakariya University Multan, Pakistan

Abstract

A walk in the morning along the green paths is called as morning walk. The purpose of this study is to find out the relationship between the morning walk and blood in the urine of the morning walkers. Morning walk is a beneficial for the good health and mind state. The people who do morning walk spend the healthy life and are protected from many diseases. To understand the relationship, we tested the urine of some of the people who do morning walk as well as the people who do not do morning walk. The results obtained shows the relationship between the morning walk and blood level in urine. There is an intermediate relation between the morning walk and the blood in urine.

Keywords: Morning Walk; Benefits; Blood in Urine; Correlation

\section{Introduction}

Morning walk is a nature gift for the healthy life. It is mostly a 30 minutes' walk in the morning, and it can change your life if you are facing the problems of obesity, diabetes and heart diseases. A morning walk is also good for the people who are suffering from the disease of joints. The persons suffering from the heart disease cannot run. The doctors asked them to have a morning walk and walk slowly instead of running. The fresh air in the morning is good for the asthma patients as well. The fresh air makes the people fresh, keep the nerves calm, make ones to be energetic and active for the whole day laborious activities. It activates and refreshes the mind and keeps the body fit Robertson [1]. In the morning the level of oxygen is high in the atmosphere and less pollution. In the morning everything gives a new look. The bird chirping and the natural scenes have a positive impact on the mind and soul. The research has shown that spending time with nature improves the health of human being $\mathrm{Oh}$ et al. [2].

There may be blood in your urine, and it is alarming situation. The appearance of the blood in the urine may be due to some reasons. In some cases, the reason for the blood in urine may be harmless. If the blood is in the urine can be seen it is called Gross hematuria. Gross hematuria is a symptom for any serious urological disease Sutton [3]. In some cases, the blood is only visible only under the electron microscope and it can only be detected after performing tests. This is called microscopic hematuria. It includes 1-10 red blood cells per high power field Cohen \& Brown [4]. The symptoms include the pink or the red color urine. The causes of the urine in the blood may be due to urinary tract infection. The urinary tract infections cause the pain and burning during urination. The blood in urine may also be due to the kidney infections. The kidney infections may be due to the bacteria. The symptoms of the kidney infection may be similar to the urinary tract infection. Another reason of blood in the urine may be due to the kidney stone. Sometime the kidney stones do not cause the pain they cause the blockage of the urinary bladder. The purpose of this study is to find the relationship between the morning walk and blood level in urine. Is there any relationship between the morning walk and blood in urine?

\section{Materials and Methods}

\section{Project Design}

We selected the people who do morning walk and also the people who do not do the morning walk. All the samples taken were from the Institute of Molecular Biology and Biotechnology Bahauddin Zakariya University Multan. Their blood level in urine was tested.

\section{Measurement of Blood in Urine}

To test the level of blood in urine we use a strip. The strips were dipped into the urine taken as a sample. After few seconds the strips showed different color. Their color was matched with the color present on the strip bottle. Every color has a specific value. In this way we tested the blood level in the urine and measure the specific value. We also come to know about the people who were hemolytic and non-hemolytic. The results have been shown in the (Table 1 ). 
Table 1: The relationship between the blood in urine and the morning walk.

\begin{tabular}{|c|c|c|c|c|}
\hline Gender & \multicolumn{2}{|c|}{ Do Morning Walk } & \multicolumn{2}{c|}{ Do Not do Morning Walk } \\
\hline & $\begin{array}{c}\text { Hemolytic } \\
\text { Positive }\end{array}$ & $\begin{array}{c}\text { Hemolytic } \\
\text { Negative }\end{array}$ & $\begin{array}{c}\text { Hemolytic } \\
\text { Positive }\end{array}$ & $\begin{array}{c}\text { Hemolytic } \\
\text { Negative }\end{array}$ \\
\hline Male & $12.5 \%$ & $87.5 \%$ & $21.73 \%$ & $78.26 \%$ \\
\hline Female & $22.22 \%$ & $77.77 \%$ & $33.33 \%$ & $66.66 \%$ \\
\hline
\end{tabular}

\section{Statistical Analysis}

We have used the M-stat software for the calculation of results. The results obtained are summarized in a table.

\section{Results and Discussion}

The results show that the persons who do morning walk have less percentage who have the blood in their urine. Most of the people who do morning walk do not secrete the blood in the urine. While on the other hand the persons who do not do morning, walk is high in proportion who have blood in their urine as compared to those who do morning walk. So, the results show that there is an intermediate level of relation between the blood in urine and morning walk as there is no significant difference of urine in blood of the persons who do morning walk and who do not do morning walk.

\section{References}

1. Robertson M (2015) Book section an early morning walk, In Experiencing the outdoors: Enhancing strategies for wellbeing Robertson M, Lawrence R, Heath G p. 1-12.

2. Oh B, Lee KJ, Zaslawski C, Yeung A, Rosenthal D, et al. (2017) Health and well-being benefits of spending time in forests: Systematic review, Environmental health and preventive medicine 22(1): 71.

3. Sutton, JM (1990) Evaluation of hematuria in adults, JAMA 263: 24752480.

4. Cohen RA, Brown RS (2003) Microscopic hematuria, New England Journal of Medicine 348: 2330-2338.

\section{Your next submission with Juniper Publishers} will reach you the below assets

- Quality Editorial service

- Swift Peer Review

- Reprints availability

- E-prints Service

- Manuscript Podcast for convenient understanding

- Global attainment for your research

- Manuscript accessibility in different formats

( Pdf, E-pub, Full Text, Audio)

- Unceasing customer service

Track the below URL for one-step submission https://juniperpublishers.com/online-submission.php 